\title{
KEGIATAN BAKTI SOSIAL MELALUI PEMBAGIAN SEMBAKO KEPADA MASYARAKAT DI PANDEMI COVID-19
}

\author{
Puji Muniarty ${ }^{1}$, Nurhayati ${ }^{2}$, Wulandari ${ }^{3}$, M Rimawan $^{4}$, Amirulmukminin $^{5}$ \\ Sekolah Tinggi Ilmu Ekonomi (STIE) Bima, NTB, Indonesia ${ }^{1}$ \\ Email:puji.stiebima@gmail.com
}

\begin{abstract}
Abstrak
Covid-19 berdampak multidimensi diberbagai sektor baik ekonomi maupun pendidikan. Saat ini penyakit ini sungguh meresahkan psikologi masyarakat karena pemberitaan diberbagai media elektronik maupun media cetak selalu menginformasikan ribuan kematian penduduk akibat positif Covid-19. Masyarakat kehilangan mata pencaharian dan menurunkan minat beli akan berbagai komoditas barang dan jasa yang diperjual belikan. Walaupun saat ini sudah berada di new normal namun secara aktivitas ekonomi masih lesu dan masyarakat kekurangan kebutuhan hidup. Merespon kondisi tersebut di Dies Natalis ke-19 Sekolah Tinggi Ilmu Ekonomi (STIE) Bima melalui kegiatan pengabdian kepada masyarakat mengadakan kegiatan bakti sosial melalui pembagian paket sembako ke masyarakat yang membutuhkan. Metode pengabdian masyarakat dilakukan dengan pendekatan secara partisipatif dengan melibatkan langsung para dosen dan mahasiswa untuk membagi secara langsung paket sembako di kelurahan Na'e dan kelurahan Sara'e sebanyak 200 paket sembako yang dilaksanakan dalam satu hari sesuai dengan isi undangan yang dishare kepada civitas akademika. Dalam pendistribusian atau pembagian paket sembako berjalan lancar dan aman serta tetap mematuhi protokoler kesehatan yang telah ditetapkan pemerintah. Diharapkan dengan bakti sosial tersebut dapat meringankan kebutuhan beban masyarakat yang terdampak langsung dari situasi pandemi Covid-19 ini. Kegiatan pengabdian kepada masyarakat ini didukung penuh oleh Ketua Sekolah Tinggi Ilmu Ekonomi (STIE) Bima, para dosen dan mahasiswa sehingga dalam pembagian paket sembako dapat terlaksana dengan baik.
\end{abstract}

Kata Kunci : Bakti sosial, Covid-19, New Normal.

\section{Abstract}

Covid-19 has a multidimensional impact in various sectors of the economy and education. Currently this disease is really disturbing the psychology of the community because news in various electronic media and print media always shows information on the death of the population due to positive Covid19 People lose their livelihoods and reduce interest in buying and selling various commodities of goods and services. Even though it is now in a new normal, economic activity is still sluggish and people lack the necessities of life. Responding to these conditions on the 19th anniversary of the Bima School of Economics (STIE), through community service activities, held social service activities through the distribution of basic food packages to people who needed basic food packages. The community service method is carried out with a participatory approach by directly involving lecturers and the community to directly distribute 200 basic food packages in Na'e and Sara'e villages which are carried out in one day according to the contents of the invitation that were shared with the academic community. The distribution or distribution of basic food packages runs smoothly and safely and complies with health protocols that have been established by the government. It is hoped that this social service can ease the burden on the needs of the people affected by the language of the COVID-19 pandemic situation. This community service activity is fully supported by the Head of the Bima High School of Economics (STIE), lecturers and students so that the distribution of basic food packages can be carried out well.

Keywords: Social service, Covid-19, New Normal. 


\section{PENDAHULUAN}

Pandemi Covid-19 merubah pola kehidupan masyarakat secara drastis tanpa terkecuali. Mewabahnya virus Corona telah mengakibatkan mobilitas perekonomian berhenti dan menurunkan kondisi perekonomian di Indonesia, bukan hanya perekonomian Indonesia saja namun juga perekonomian dunia. Sehingga banyak badan industri yang aktivitas produksinya berhenti atau jam operasionalnya berkurang serta banyak masyarakat yang kehilangan sumber mata pencaharaian maupun jam kerja yang semakin berkurang. Hal ini akhirnya berdampak pada penurunan sumber pendapatan masyarakat. April 2021 kasus terkonfirmasi Covid-19 Kota Bima NTB yaitu sebanyak 1048 yang terdiri atas masih isolasi sebanyak 43 orang, sembuh sebanyak 966 orang dan meninggal sebanyak 39 orang, (https://covid19.bimakota.go.id). Melihat data tersebut terlihat jelas bahwa dengan adanya Covid-19 membawa dampak yang cukup signifikan disegala sektor terutama sektor mikro daerah yang ada di Kota Bima. Semua aktivitas kegiatan baik formal maupun tidak formal dibatasi guna agar tidak meningkatnya jumlah masyarakat positif Covid-19.

Minat beli dan konsumsi akan berbagai komoditas barang dan jasa oleh masyarakat dimasa pandemi Covid-19 mengalami penurunan bila dibandingkan tahuntahun sebelumnya karena secara psikologi masyarakat sangat takut untuk melakukan kontak langsung dengan orang-orang atau pembelian secara langsung hal ini terjadi karena berbagai pemberitaan dimedia elektronik yang menyatakan setiap menit angka kematian akibat dari Covid-19 selalu meningkat. Untuk memutuskan atau mencegah penyebaran virus Covid-19, pemerintah menyarankan kepada masyarakat untuk tinggal dirumah termasuk ibadah, sekolah, bekerja dan kegiatan lainnya kecuali ada urusan yang mendesak (Ketua Ikatan Ahli Kesehatan Masyarakat Indonesia, 2020) dalam (kompas.com, 2020). Namun pada 1 Juni 2020 lalu, pemerintah sedikit melonggarkan kebijakan terkait Covid-19 (kompas.com, 2020) kebijakan tersebut disebut New Normal. Walaupun sudah berada di new normal masyarakat tetap dihimbau untuk tetap mematuhi protokoler kesehatan dengan memakai masker, mencuci tangan, dan menjaga jarak.

Merespon kondisi tersebut pada Dies Natalis ke-19 Sekolah Tinggi Ilmu Ekonomi (STIE) Bima melalui kegiatan pengabdian kepada masyarakat yang merupakan bagian dari Tri Darma Perguruan Tinggi yang biasanya berupa kegiatan pemberian keterampilan atau pelatihan yang berbasis pada bidang keahlian dosen Tim PKM. Namun di tahun 2021, semua dialihkan pada bentuk kegiatan yang bertujuan membantu meringankan beban masyarakat terdampak Covid-19. Masyarakat terdampak meliputi masyarakat umum khususnya masyarakat yang berada disisir bantaran sungai dan keluarga PKH. Salah satu wujud kegiatan tersebut berupa pembagian paket sembako. Pelaksanaan kegiatan PKM ini dikelola oleh Lembaga Pengabdian Kepada Masyarakat (LP2M). Dalam pembagian paket sembako tetap memperhatikan protokoler kesehatan seperti yang anjurkan oleh tim kesehatan 
pemerintah tetap memakai masker, tidak berjabat tangan dan menjaga jarak dengan warga masyarakat.

Kegiatan bakti sosial merupakan salah satu kegiatan wujud dari rasa kemanusiaan antara sesama guna mewujudkan rasa cinta, rasa saling menolong, rasa saling peduli kepada masyarakat yang membutuhkan uluran tangan dari berbagai pihak. Berbagi sembako adalah salah satu cabang dari bakti sosial yang merupakan bentuk bagian dari pengabdian masyarakat (Wikipedia, 2018). Dengan kegiatan ini dapat terjalin tali silaturahmi dan persaudaraan antar sesama sehingga terbentuk rasa kekerabatan antara masyarakat dengan civutas akademika STIE Bima. Tujuan dari kegiatan bakti sosial ini yang dilakukan ini untuk membantu masyarakat yang terkena dampak Covid19 dan masyarakat yang terkena banjir dengan harapan dapat meringankan beban kebutuhan masyarakat.

\section{METODE}

Kegiatan bakti sosial dilakukan di Kelurahan Na'E dan Kelurahan Sara'e Kecamatan Rasana'e Barat Kota Bima, NTB. Metode yang digunakan yaitu pengabdian kepada masyarakat dalam bentuk pembagian paket sembako kapada masyarakat yang terkena Covid-19 yang berada disisir bantaran sungai termasuk keluarga PKH dengan target jangkauan 200 kepala keluarga. Untuk melakukan kegiatan pengabdian ini maka tahapan yang dilakukan yaitu :

1. Studi pendahuluan dilakukan untuk mengetahui keadaan riil masyarakat untuk dijadikan kelompok sasaran kegiatan pengabdian yaitu masyarakat yang berada disisir bantaran sungai observasi ini dilakukan agar pembagian paket sembako dapat tersebar secara merata.

2. Persiapan pada tahap ini tim pengabdian masyarakat yang menyiapkan berbagai keperluan yang dibutuhkan dalam pembagian paket sembako seperti beras, minyak goreng, mie instan, dan lain-lain lalu dilanjutkan kan dengan pengemasan bahanbahan tersebut ke dalam plastik untuk mudah didistribusikan.

3. Pendistribusian dalam tahap ini dosen dan mahasiswa melakukan pendistribusian atau pembagian paket sembako kepada sasaran masyarakat hasil studi pendahuluan yang membutuhkan yang tersebar disekitar bantaran sungai.

4. Laporan kegiata dalam tahap ini tim pengabdian kepada masyarakat membuat laporan kegiatan bakti sosial yang dipublikasikan media cetak online lokal yang ada di Kota Bima.

\section{HASIL DAN PEMBAHASAN}

Kegiatan ini dalam jangka waktu 1 (satu) hari sesuai dengan undangan yang disebarkan kepada para dosen dan mahasiswa termasuk perwakilan beberapa UKM yang ada di Sekolah Tinggi Ilmu Ekonomi (STIE) Bima dari jam 09.oo wita sampai dengan selesai. Kegiatan ini merupakan bentuk dari kegiatan pengabdian kepada masyarakat dalam wujud bakti sosial pembagian paket sembako kepada masyarakat yang membutuhkan yang berada di lingkungan Kelurahan Na'e dan Kelurahan Sara'e. Paket sembako yang dibagikan dipersiapkan secara maksimal dengan pengemasan yang 
cukup menarik dan tidak lupa untuk mempermudahkan penyaluran paket sembako digunakan transportasi kampus Sekolah Tinggi Ilmu Ekonomi (STIE) Bima.
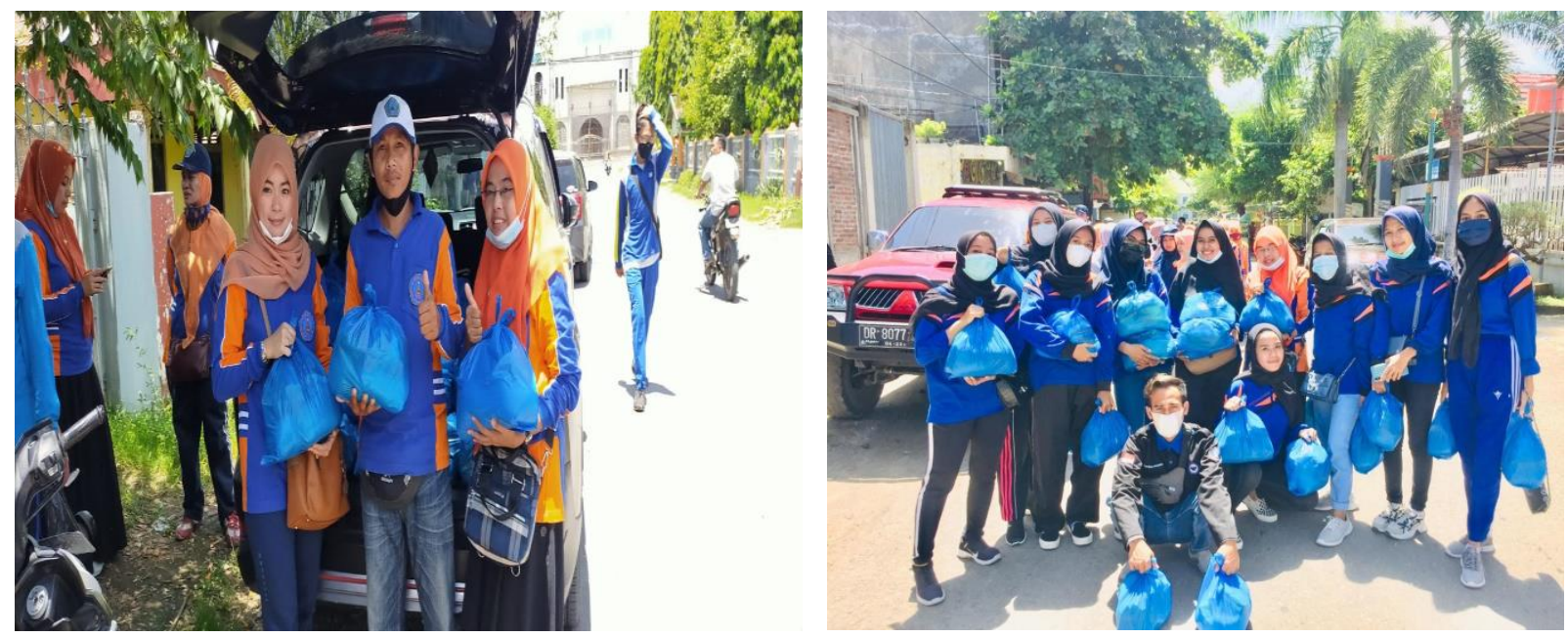

Gambar 1. Paket Sembako Yang Akan dibagikan Kepada Masyarakat

Dalam tahap pendistribusian atau pembagian paket sembako, dosen dan mahasiswa menggunakan pendekatan partisipatif. Pendekatan partisipatif menekankan kepada pengumpulan data dan proses pelaksanaan yang melibatkan langsung peranan peneliti, dengan cara melihat fenomena lebih luas dan akan disesuaikan dengan kondisi sosial masyarakat yang tengah diteliti, (Rahman, 2019). Pendistribusian dan pembagian paket sembako disesuaikan didasarkan pada kondisi masyarakat yang benar-benar membutuhkandan berada disisir bantaran sungai termasuk keluarga penerima bantuan $\mathrm{PKH}$.

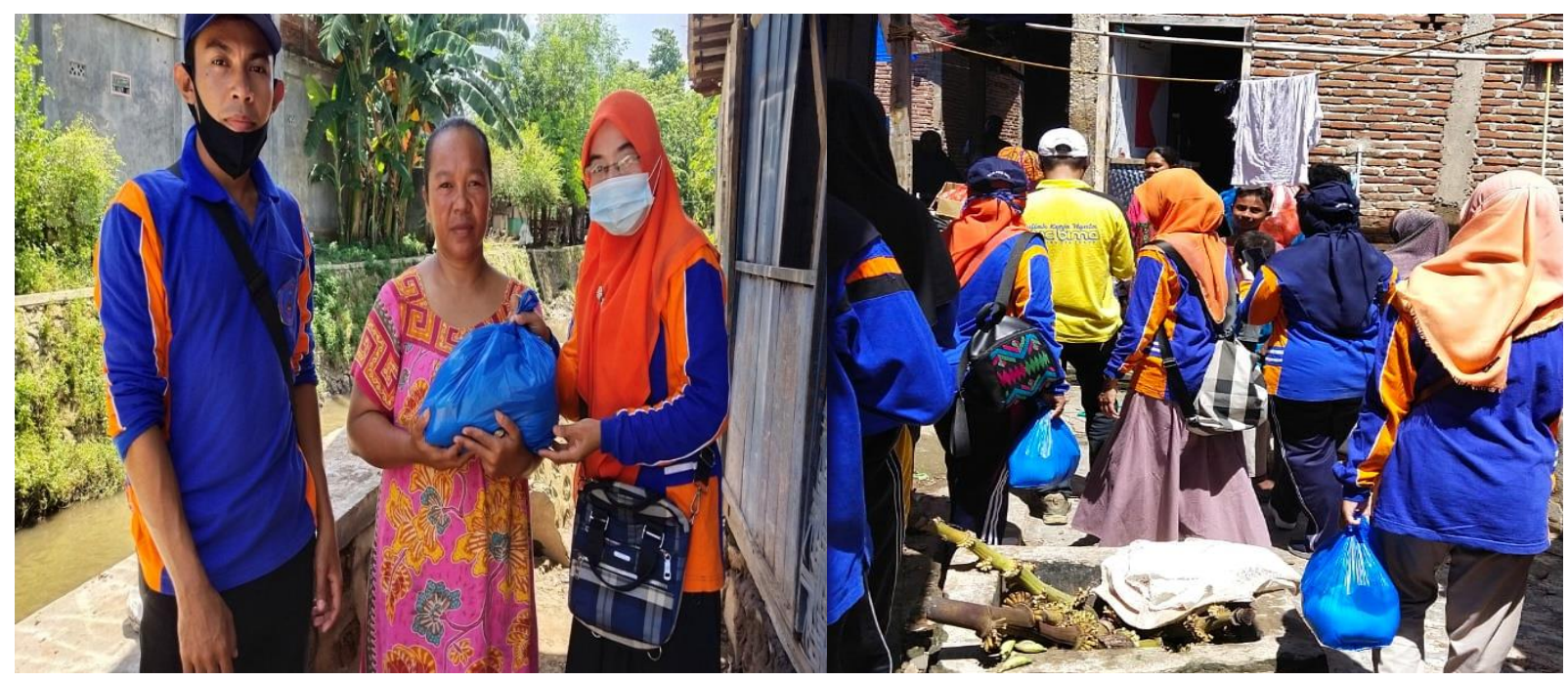

Gambar 2. Pembagian Paket Sembako

Dalam pembagian paket sembako dilakukan secara langsung dengan turun ke masing-masing rumah warga yang mebutuhkan seembako melalui jarak yang aman dan melibatkan mahasiswa artinya tetap mematuhi protoler kesehatan yang ditetapkan 
yaitu dengan tetap memakai masker, tidak berjabat tangan dan menjaga jarak. Sehingga dalam hal ini dapat disimpulkan bahwa ada proses interaksi langsung kami dengan target awal kami. Dengan adanya pemberian oaket sembako diharapkan memberikan manfaat kepada masyarakat apalagi di Covid-19 sungguh kebutuhan masyarakat terbatas dan dikerenakan masih lesunya perekonomian sebagai sumber penghasilan masyarakat untuk menopang kebutuhan sehari-hari.

Setelah kegiatan berlangsung maka tim pengabdian kepada masyarakat Sekolah Tinggi Ilmu Ekonomi (STIE) Bima dari hasil kegiatan bakti sosial tersebut dengan mempublikasikan aktivitas yang ada di media koran online yang dapat diakses melalui https://kahaba.net/berita-kota-bima/84541/dies-natalis-ke-19-stie-bima-bagikanratusan-sembako.html

\section{KESIMPULAN}

Kegiatan pengabdian kepada masyarakat dalam rangka Dies Natalis Sekolah Tinggi Ilmu Ekonomi (STIE) Bima dalam bentuk kegiatan bakti sosial pembagian paket sembako merupakan bentuk peran dari civitas akademika yang berada ditengah masyarakat yang ada di Keluruhan Na'e dan Kelurahan Sara'e di Kota Bima yang dapat membantu meringankan kebutuhan masayarakat sekitar yang terkena dampak Covid19. Kegiatan ini juga didukung penuh oleh para dosen dan mahasiswa yang tergabung dalam tim pengabdian masyarakat sehingga kegiatan ini dapat terlaksana dengan baik dan lancar. Diharapkan kegiatan pengabdian kepada masyarakat selanjutnya yaitu dengan memperluas objek yang akan diberi paket sembako dan kerja sama dengan pemerintah setempat sehingga diperoleh pemerataan yang lebih.

\section{UCAPAN TERIMA KASIH}

Ucapan terima kasih kami ucapkan kepada Ketua Sekolah Tinggi Ilmu Ekonomi (STIE) Bima dan civitas akademika yang telah memberikan dukungan dan kontribusi pada pelaksanaan kegiatan ini sehingga berjalan sesuai dengan yang telah direncanakan sebelumnya. Tim penulis mengucapkan terima kasih kepada Ketua RT setempat yang telah membantu kami dalam pengumpulan data sehingga kegiatan ini dapat berjalan lancar dan baik.

\section{REFERENSI}

Al-Faruqi, Radian Atho, Roshidayah Roshidayah, Husnia Najmah, \& Rosa Nikmatul Fajri. (2020). Kegiatan Bakti Sosial Untuk Membantu Ekonomi Lansia Di Desa Jambeyan Pada Era New Normal. SELAPARANG: Jurnal Pengabdian Masyarakat Berkemajuan 4(1), 617.

Caesar, David Laksamana, Rochmatun Nafi'ah, \& Lilis Sugiarti. (2020). Gerakan Peduli Covid-19 Di Lingkungan Kampus Stikes Cendekia Utama Kudus. Jurnal Pengabdian Kesehatan 3(2), 179-88.

Karuniawati, B, E N Fauziandari, dkk. (2020). Pemberian Sembako Dan Promosi 
Kesehatan Pada Warga Terdampak Covid-19 Di Dusun Cengkehan Desa Wukirsari Kabupaten Bantul. Jurnal, 2(2),16-20.

Pramanik, Nuniek Dewi. (2020). Dampak Bantuan Paket Sembako Dan Bantuan Langsung Tunai Terhadap Kelangsungan Hidup Masyarakat Padalarang Pada Masa Pandemi Covid 19. Jurnal Ekonomi, Sosial dan Humaniora o1(12), 113-20.

Rahman, Arief. (2019). Pendekatan Partisipatif Dalam Pengembangan Komunitas. Modul Pengembangan Komunitas. Bogor: Program Prencanaan dan Pengembangan Komunitas $\mathrm{P}_{4} \mathrm{~W}$-LPPM Institutue Pertanian Bogor.

Tambunan, E, M L Purba, dkk. (2020). Pendampingan Gerakan Bakti Sosial Berbagi Paket Sembako Peduli Covid-19 Hima Manajemen Universitas Sari Mutiara Indonesia. Jurnal Abdimas, 58-63.

https://covidı.bimakota.go.id 